\title{
CONTRIBUTOS PARA A HISTÓRIA DE UM LUGAR. O TÚMULO 1 DE CAMPO DE CAPARINHO, VILAR DE PERDIZES, MONTALEGRE, NO CONTEXTO MICRO-REGIONAL
}

\author{
AnA M. S. BetTencourT*, ANTÓNio Dinis* \& Luís Loureiro*
}

Resumo

Abstract

\section{INTRODUÇÃo}

A descoberta desta estrutura ocorreu em Maio de 2002 quando pretendíamos identificar vestígios arqueológicos que se pudessem relacionar, em termos espaciais e cronológico-culturais, com as diversas gravuras rupestres encontradas em Campo de Caparinho e parcialmente objecto de publicação (BetTenCourt 2004, 2006; BetTenCOURT et al. 2004; BETTENCOURT \& Dinis 2007).

Após as devidas formalidades, com o então Instituto Português de Arqueologia, procedemos à escavação deste imóvel durante o mês de Setembro de 2003.

Os trabalhos realizaram-se no âmbito do projecto Manifestações simbólicas e povoamento do Neolítico à Idade do Ferro entre o alto Cávado e o alto Tâmega (Norte de Portugal), inscrito no Centro de Ciências Históricas e Sociais (CCHS) da Universidade do Minho, com a referência HIST/02/PC.01.

\footnotetext{
* Centro de Investigação Transdisciplinar de Cultura, Espaço e Memória - CITCEM (Univ. do Porto e Univ.Minho).
} E-mail: anabett@uaum.uminho.pt; 


\section{LocalizaÇão e CONTEXTos: GEOMORFOLÓGico, AMBIENTAL E ARQUEOLÓGICO}

O Campo de Caparinho localiza-se no distrito de Vila Real, concelho de Montalegre, freguesia de Vilar de Perdizes (S. Miguel), na zona fronteiriça com Espanha (Fig. 1).

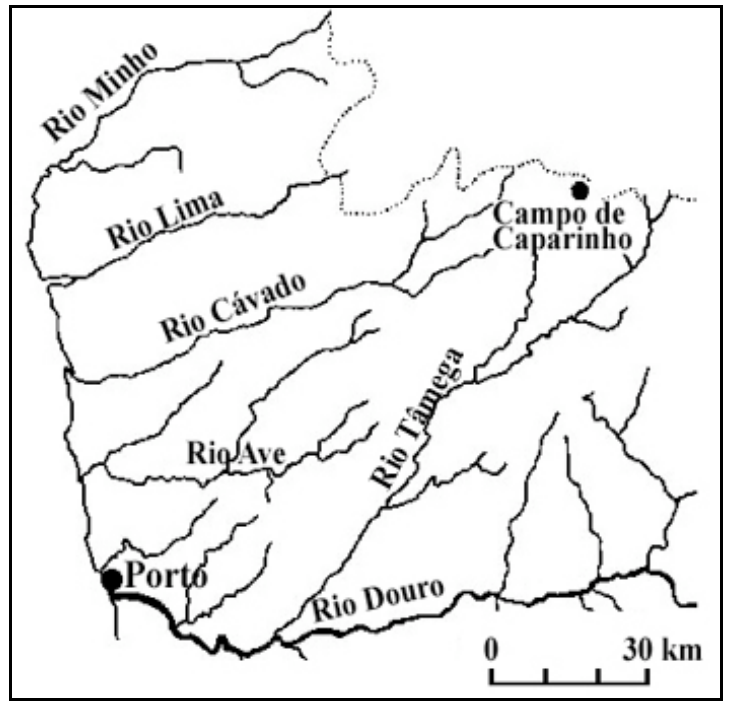

Fig. 1 - Localização de Campo de Caparinho.

Fig. 1 - Location of Campo de Caparinho.

Trata-se de um topónimo que abarca uma área com alguns hectares, situando-se o monumento em estudo numa pequena plataforma de meia vertente, existente na margem esquerda do rio Assureira, afluente do rio Tâmega. O local, intensamente agricultado até meados do séc. XX, está actualmente coberto de vegetação arbustiva e herbácea. Nas cercanias crescem carvalhos e castanheiros, alguns deles, de plantação recente.

$\mathrm{O}$ acesso é relativamente fácil, podendo fazer-se pelo estradão que vai de Vilar de Perdizes em direcção à capela de Santa Marinha.

No local conhecido por Pardelhas é necessário virar à direita por uma caminho carreteiro. As coordenadas geográficas segundo a Carta Militar de Portugal na escala $1: 25000$, folha 20 - são as seguintes (Fig. 2):

Latitude: $41^{\circ} 51^{\prime} 55^{\prime}, \mathrm{N}(\mathrm{GW})$

Longitude: $7^{\circ} 36^{\prime} 15^{\prime \prime} \mathrm{W}$

Altitude máxima: 730/720 m.

Segundo a Carta Geológica de Portugal, na escala 1:50 000, folha 2-D (Vilar de Perdizes), o substrato rochoso da região é composto por granitos alcalinos de grão médio a grosseiro, de duas micas, que afloram à superfície (TEIXEIRA \& ASSUNÇÃO,
1970), embora, localmente se registem afloramentos de rochas metamórficas, algumas de tipo metagrauvaques (Inf. oral de Isabel Caetano Alves).

A área é rica em vestígios arqueológicos.

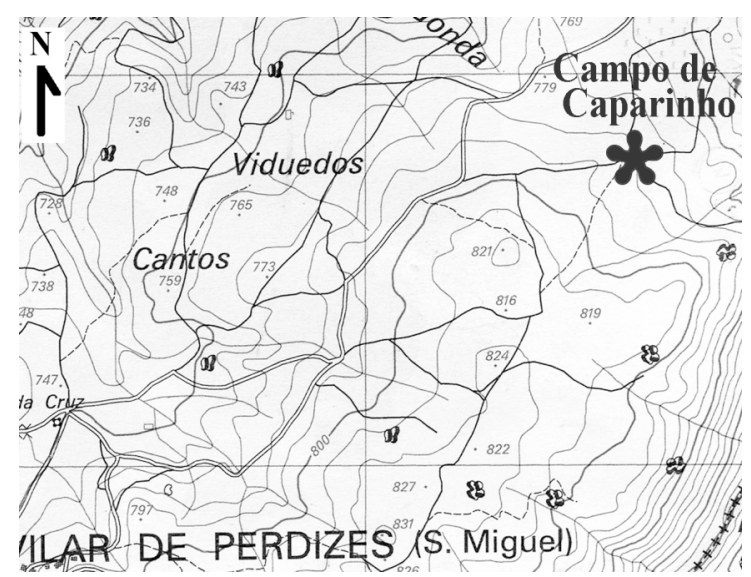

Fig. 2 - Localização do Túmulo 1 de Campo de Caparinho. Excerto da Carta Militar de Portugal, 1:25000.

Fig. 2 - Location of Campo de Caparinho Tomb 1, in the “Carta Militar de Portugal”, 1:25000.

A cerca de $15 \mathrm{~m}$ para noroeste do túmulo, existe um afloramento granítico aplanado onde covinhas naturais e de origem antrópica, se associam a sulcos efectuados por picotagem. Trata-se da gravura 1 de Campo de Caparinho (Fig. 3). Nos muros de divisão de propriedades existentes nas imediações, a norte e noroeste, foram encontradas duas estelas e a gravura 3 - um afloramento vertical com motivos abstractos (BETTENCOURT, 2004, 2006).

A leste, já em plena vertente virada ao rio, fica a impressionante estação de arte rupestre do Penedo do Matrimónio (BETTENCOURT et al. 2004). Na envolvência registam-se, ainda, diversas jazidas onde ocorrem fragmentos cerâmicos e líticos inseríveis na Pré-História Recente. Entre estes destacamos a Crista de Caparinho, uma pequena pala quartzítica com gravuras na superfície externa, associada a moventes manuais e a recipientes cerâmicos datados radiometricamente da $2^{\mathrm{a}}$ metade do IV milénio AC, a cerca de uma centena de metros a norte-noroeste do túmulo em estudo (BETTENCOURT \& DINIS, 2007).

A 100 metros para oeste deste imóvel destacamos, ainda, a grande acumulação de núcleos de quartzo leitoso, talvez a indiciar a existência de uma área de exploração intensiva deste tipo de matéria-prima. 


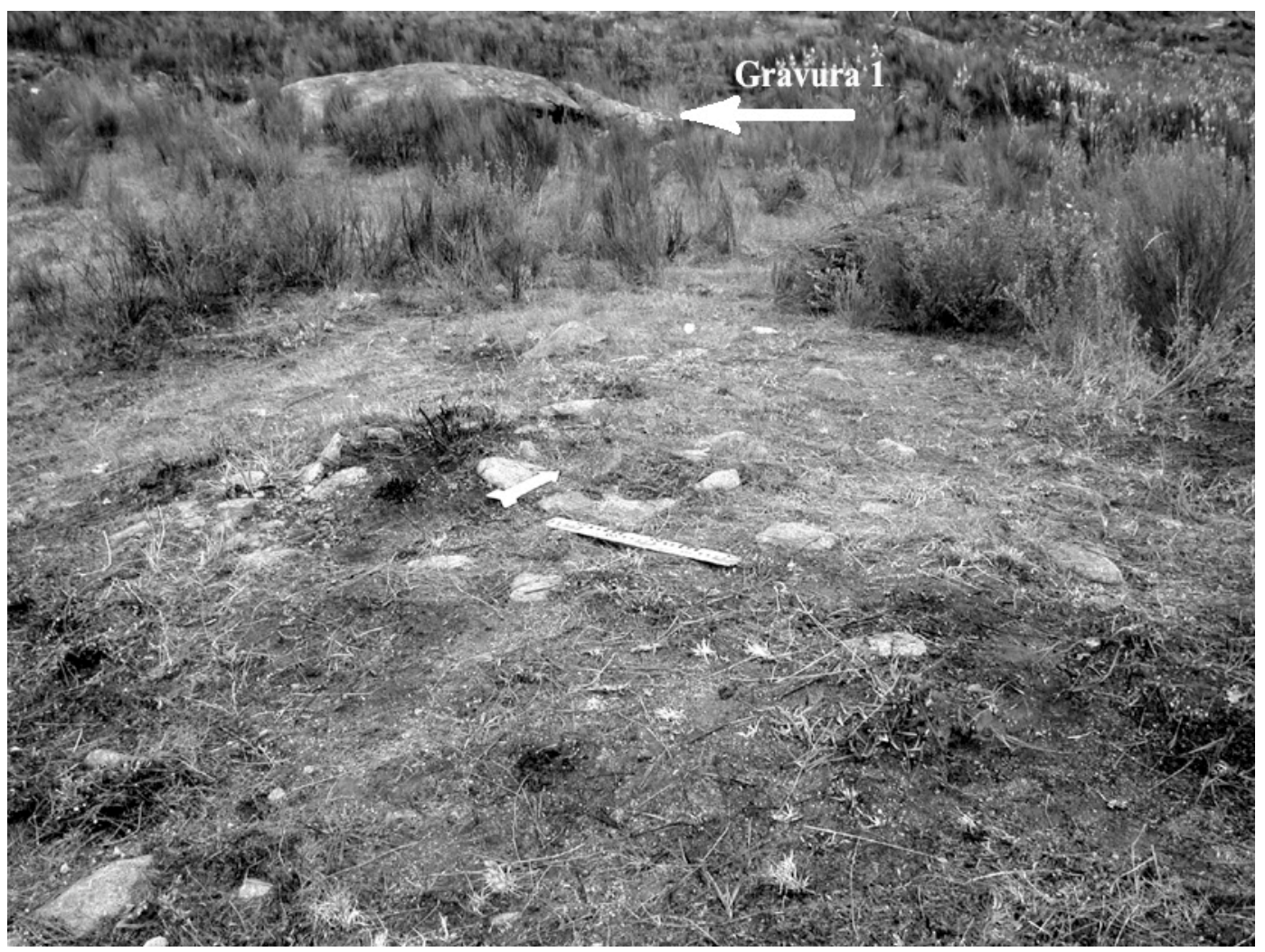

Fig. 3 - Fotografia geral do monumento antes da escavação, com a localização da gravura 1 no afloramento em segundo plano.

Fig. 3 - General view of the monument before the archeological digging, with the location of the outcrop with the engravings $n^{\circ} 1$ in the background.

\section{Metodologia}

Iniciámos os trabalhos neste túmulo pela limpeza do coberto vegetal, tendo, de seguida, quadriculado a área a escavar com uma malha de $1 \mathrm{x} 1 \mathrm{~m}$. Foi efectuado o desenho superficial à escala 1:20 (Fig. 4) e o levantamento topográfico do montículo à escala de 1:50 (Fig. 5). Por impossibilidade de ligação à rede topográfica nacional, escolhemos um ponto de referência ao qual atribuímos a cota $721.99 \mathrm{~m}$. O local eleito foi o ponto mais elevado de um afloramento granítico situado a $4 \mathrm{~m}$ para oeste do túmulo que tem a particularidade de conter entalhes rectangulares de origem antrópica, testemunho de formas tradicionais de extracção de pedra.

Posteriormente, procedemos à decapagem da camada humosa em vários quadrados, com o objectivo de inferirmos a arquitectura superficial do monumento, na direcção Norte-Sul e Este-Oeste.

Abrimos, assim, os quadrados A2, B2, B3, C1, $\mathrm{C} 2, \mathrm{C} 3, \mathrm{C} 4, \mathrm{C} 5, \mathrm{D} 3$ e E3. Após a sua decapagem inicial e por forma a reduzir ao mínimo a destruição deste imóvel, optámos por escavar, até à rocha de base, apenas os quadrados C1, C2, C3, C4 e C5, ou seja, as sanjas Sul e Norte. Tal, permitiu-nos obter dois perfis estratigráficos, passando pela área da câmara, intensamente perturbada.

A decapagem processou-se pela extracção das camadas naturais, de forma faseada quando tal se justificava. $\mathrm{O}$ desmantelamento da estrutura pétrea foi efectuado tendo em atenção a detecção de diversos tipos e colorações de rochas, artefactos líticos e blocos com formas sensivelmente antropomórficas. Em todos os desenhos registámos, com tramas distintas, os diversos tipos de rocha usados na composição da estrutura tumular.

Após a escavação o monumento foi tapado com geotêxtil, terra e pedra. De forma a repor a morfologia original do sítio.

O espólio cerâmico e lítico, proveniente da escavação, deu entrada no Museu Regional de Arqueologia D. Diogo de Sousa, em Braga. Os ecofactos recolhidos foram enviados para análises de antracologia, efectuadas por Isabel Figueiral e os restantes para datações por radiocarbono. Estas realizaram-se no laboratório Beta Analityc Inc, em Miami, USA. 


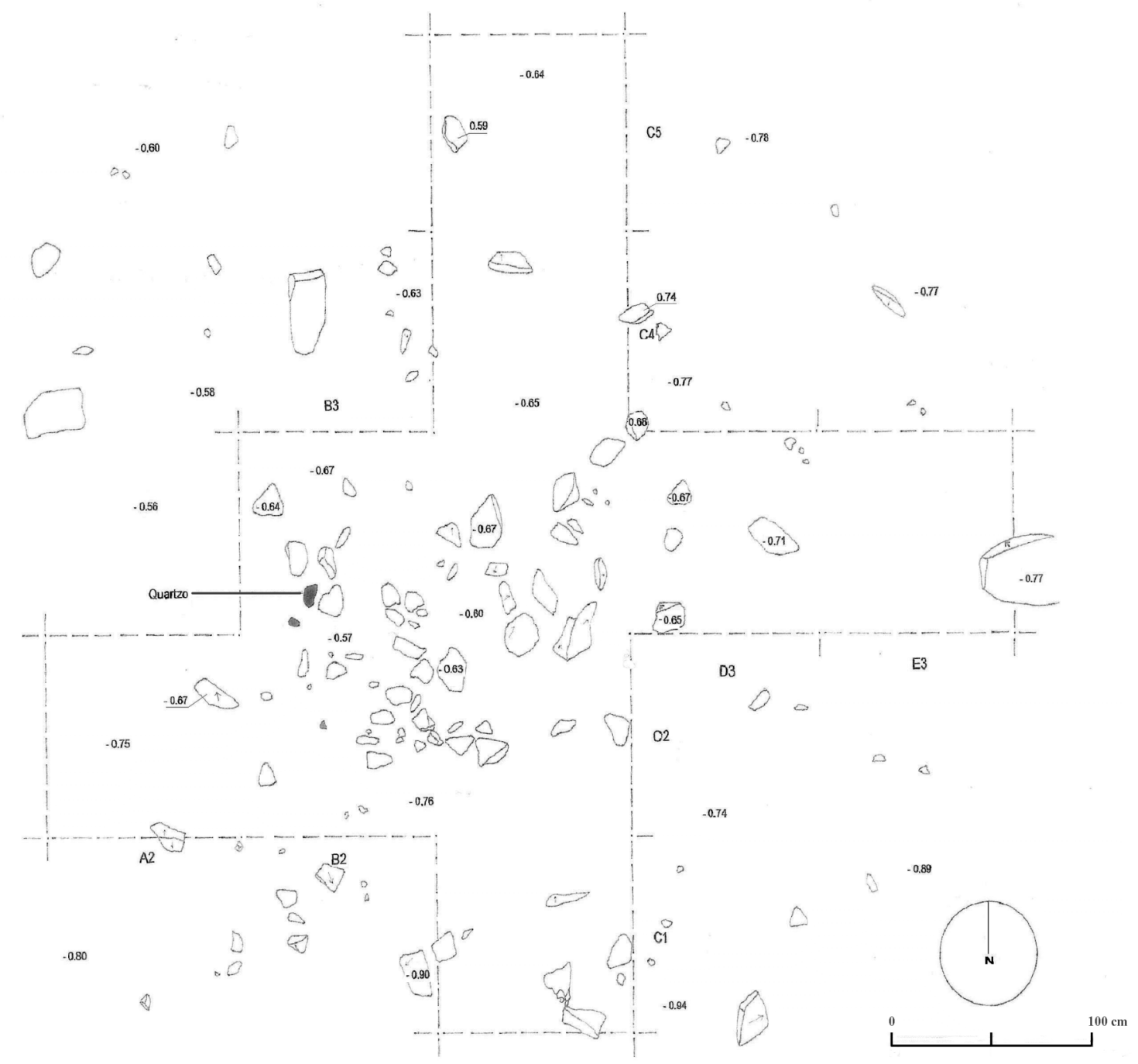

Fig. 4 - Desenho da superfície da área do monumento.

Fig. 4 - Design of the surface of the monument.

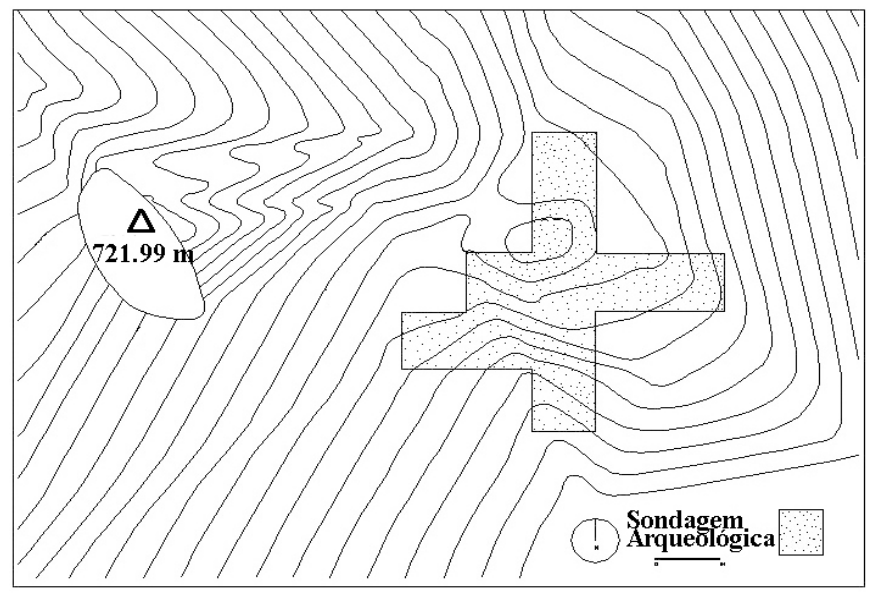

Fig. 5 - Levantamento topográfico da área do túmulo com implantação da quadrícula, à escala 1:50.

Fig. 5 - Topographic survey of the tomb area with deployment of the grid. Scale 1: 50. 


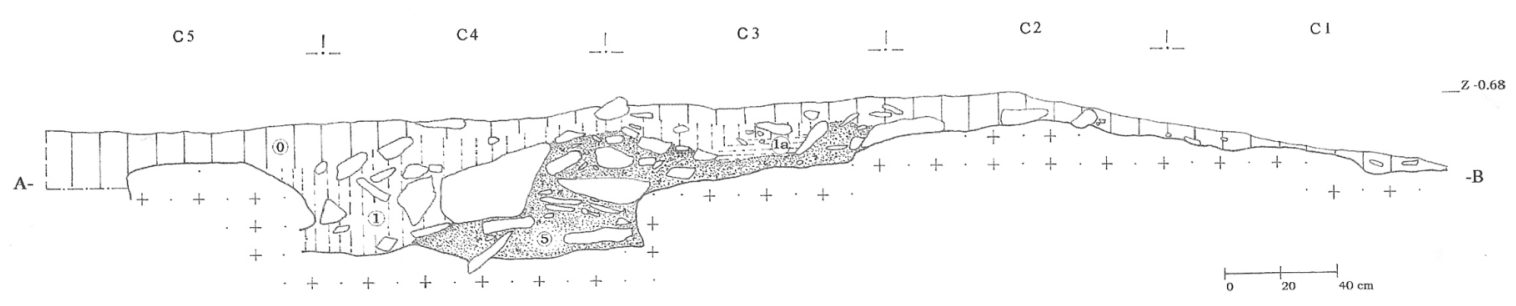

Fig. 6 - Perfil Este do túmulo.

Fig. 6 - Stratigraphic profile of the tomb, East side.
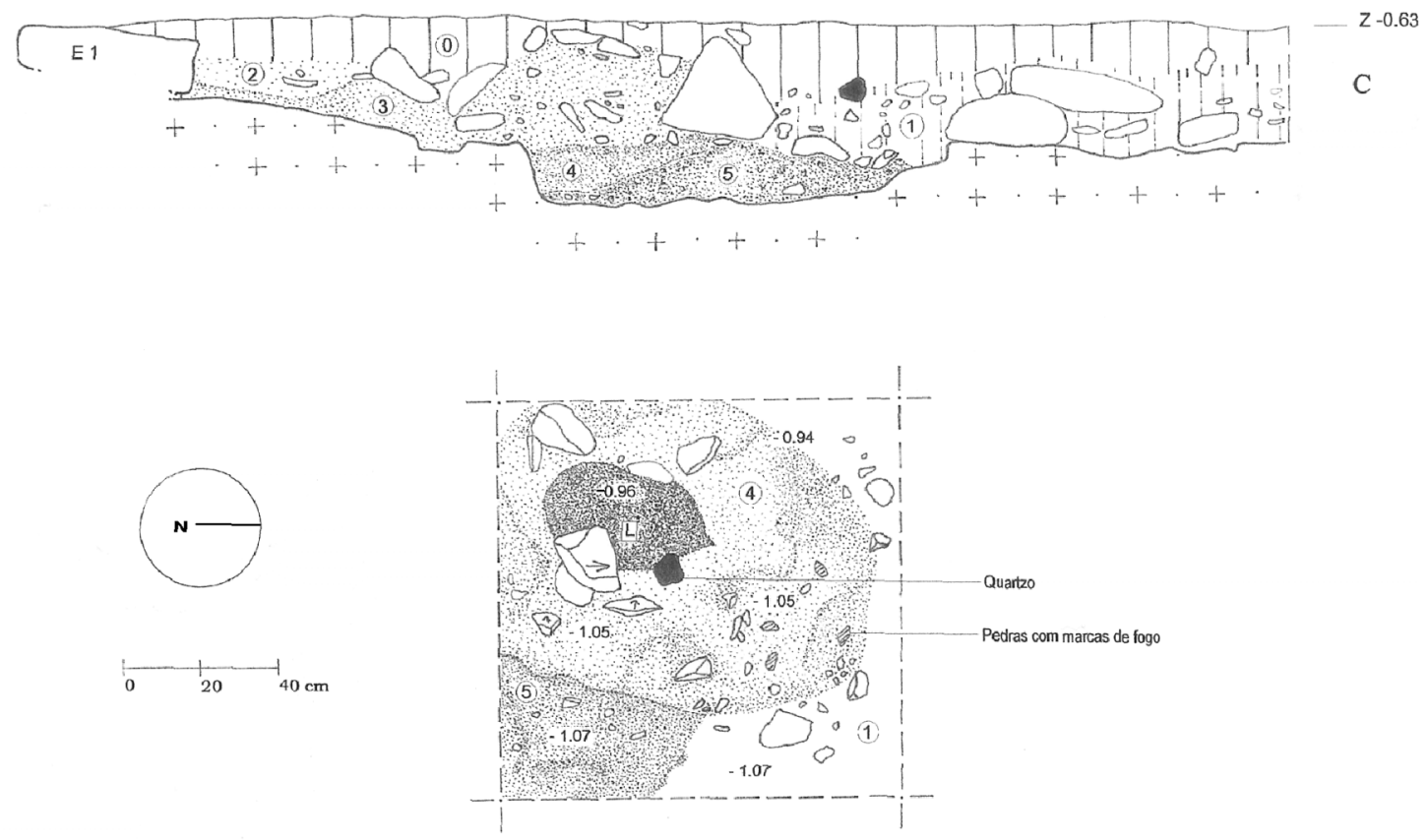

C4

Fig. 7 - Perfil Oeste, parcial, e planta da estrutura de combustão do quadrado C4.

Fig. 7 - Stratigraphic profile of the tomb (West side) with the fireplace of the C4. 


\section{EschVaÇÃo}

Apesar do estado de destruição a que tinha sido sujeito este monumento, as suas características estratigráficas permitiram, ainda, reconstituir alguns dos seus aspectos construtivos.

\subsection{Estratigrafia Sanjas Norte - Sul e Câmara}

Nos quadrados C1, C2, C3, C4 e C5, a estratigrafia apresentava a sequência (Fig. 6 e 7) descrita a seguir.

Camada 0 - terra heterogénea, castanha escura, com manchas cinzentas e carvões resultantes de incêndios recentes. Apresentava textura arenolimosa, granulosa, nada compacta, com inclusões de raízes. Corresponde à camada humosa.

Camada 1 - terra castanha, menos heterogénea do que a anterior, areno-limosa, nada compacta, granulosa. Poderá corresponder a terras do tumulus misturadas com a camada humosa.

Camada 1a - terra castanha mais escura, arenolimosa, medianamente compacta. Corresponde a terras parciais do tumulus.

Camada 2 - terra amarela, homogénea, nada compacta, de granulosidade muito fina, similar à camada 5 mas ocorrendo na área da câmara.

Camada 3 - terra castanha, areno-limosa, medianamente compacta, com alguns carvões. Corresponde a terras do enchimento do contraforte, embora com o desmembramento da câmara tenha ocupado o seu interior. É parcial.

Camada 4 - terra cinzenta com cinzas e carvões abundantes, nada compactas, contendo calhaus de médio porte. Corresponde a terras em contacto com uma estrutura de combustão existente por baixo e na periferia do contraforte. Ocorre, parcialmente, no quadrado $\mathrm{C} 4$.

Camada 5 - terra amarela, nada compacta, de granulosidade muito fina, resultante, quer da rocha de base em desintegração, quer da desintegração das pedras do contraforte. Por estes motivos pode ocorrer na base do monumento ou misturar-se com a camada 3 .

Ao analisarmos a estratigrafia do monumento verificou-se, de imediato, que a câmara já não continha sedimentos antigos, in situ, e que as terras do tumulus, onde este existia, estavam muito perturbadas pela camada humosa. Também foi possível perceber que o monumento foi construído directamente sobre o substrato rochoso, constituído por uma rocha metamórfica do tipo metagrauvaque, não existindo, portanto, qualquer indício de paleosolo.

\subsection{Arquitectura}

\subsubsection{O tumulus}

O tumulus artificial que inicialmente constituiria parte integrante deste monumento encontrava-se extremamente danificado, com excepção da área ocupada pelos quadrados C3 e C4, onde foi possível, a partir da estratigrafia, perceber algumas das suas características construtivas. Verificámos, assim, que teria existido um contraforte lítico efectuado directamente sobre o afloramento, já então, em estado de desintegração parcial. Tal facto, permitiu o aproveitamento da pedra local na construção desta estrutura, numa optimização de recursos. Aliás, as dimensões das pedras do contraforte eram semelhantes às lajes que se iam desintegrando da rocha de base. Apesar desta preferência pela rocha local o contraforte continha, ainda, alguns calhaus de quartzo leitoso e de feldspato, de média e pequena dimensões, que se espalhavam, de forma sensivelmente regular, pelos diferentes quadrados numa visível intencionalidade. Alguns xistos, ou outras rochas metamórficas eram mais raras mas apareceram nos quadrados B2, B3 e C4, a oeste e norte da câmara funerária, respectivamente.

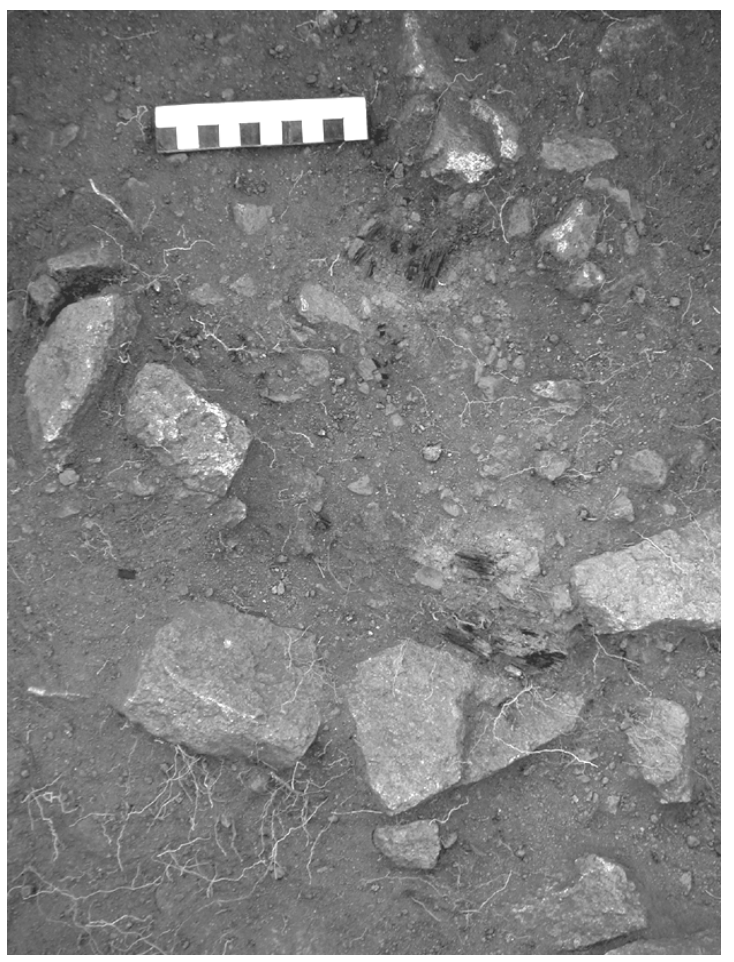

Fig. 8 - Estrutura de combustão.

Fig. 8 - Fireplace. 
O imbricado de blocos líticos que compunha o contraforte estava bem estruturado sendo o seu fecho construído por blocos de maior dimensão, dispostos obliquamente, à cota média de $-1.11 \mathrm{~m}$. A fase terminal desta estrutura assentava sobre um lajeado de pedras colocadas, sensivelmente, na horizontal. Sobre parte deste empedrado, mais precisamente no quadrado $\mathrm{C} 4$, foi efectuada uma lareira, de contorno sub-circular, composta por alguns calhaus fumigados e por uma grande acumulação de carvões (Fig. 7 e 8).
O topo do contraforte parece ter sido perturbado, a sudoeste e a noroeste dos quadrados C3 e C4, respectivamente, dada a disposição dos blocos líticos que aqui formavam uma espécie de nicho rectangular, atípico. Esta eventual perturbação, não forneceu carvões nem qualquer outro tipo de espólio que indiciasse, com segurança, tratar-se de uma reutilização secundária de época pré-histórica, pelo que poderá ter resultado da acção das raízes, tendo em conta que esta estrutura se encontrava à superfície e muito perturbada em inúmeros locais.

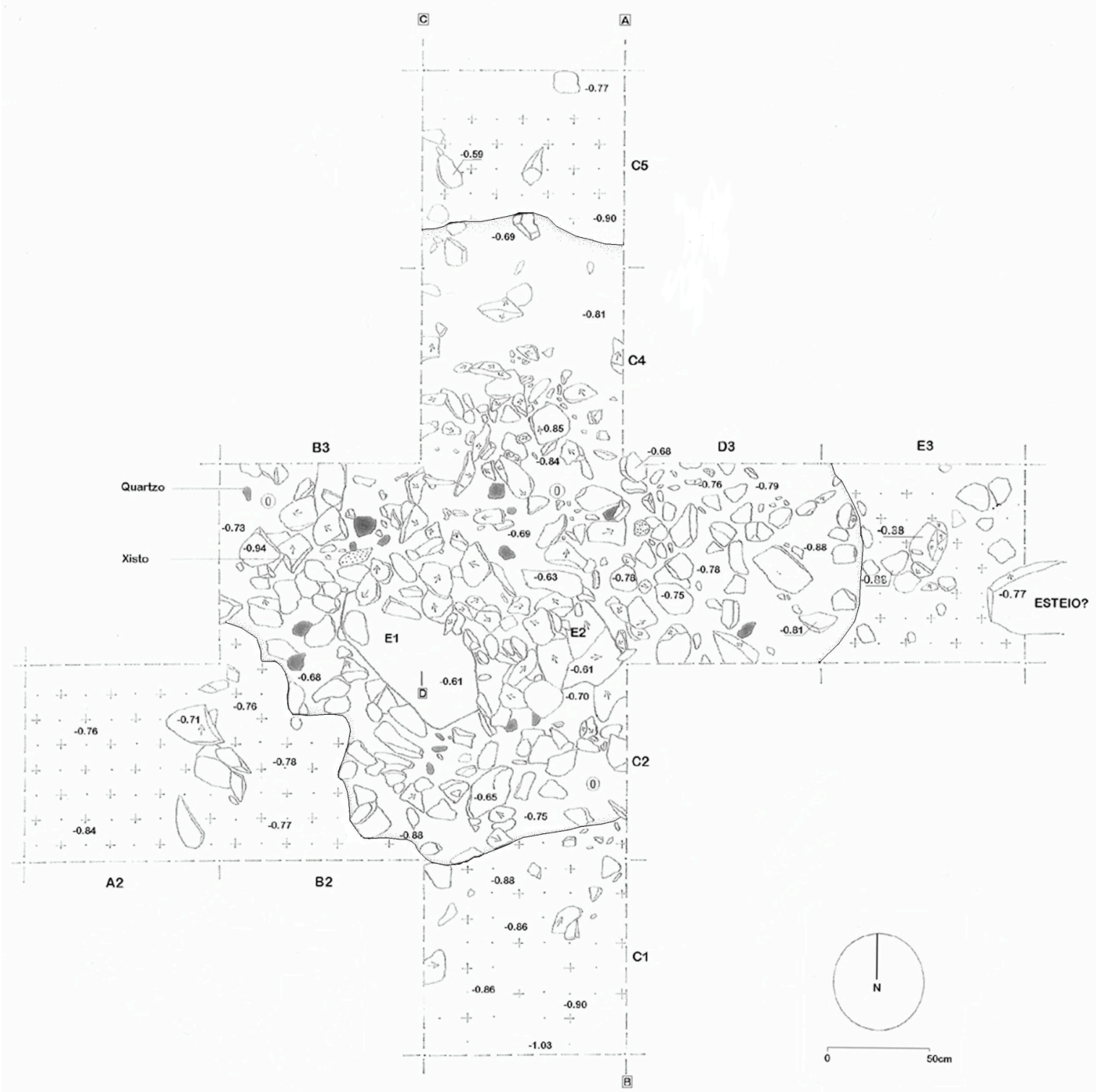

Fig. 9 - Pormenor do monumento após a decapagem da camada humosa. A linha mais carregada delimita a área do contraforte.

Fig. 9 - Detail of the monument after the excavation of the layer humus. The most loaded line delimiting the area of the counterfort of the funerary chamber. 


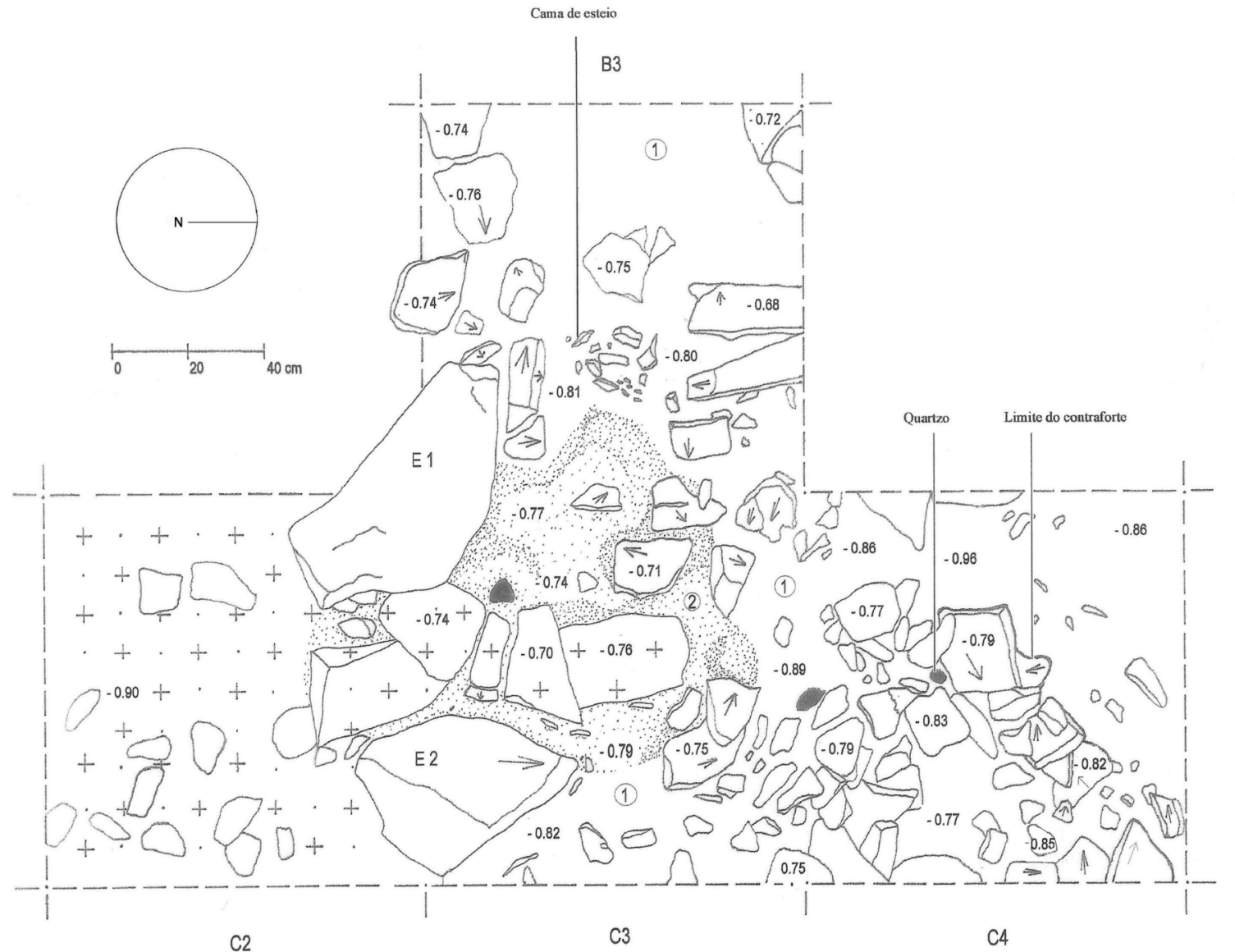

Fig. 10 - Pormenor da área da câmara. De notar uma cama de esteio, no quadrado B3.

Fig. 10 - Detail of the area of the funerary chamber.

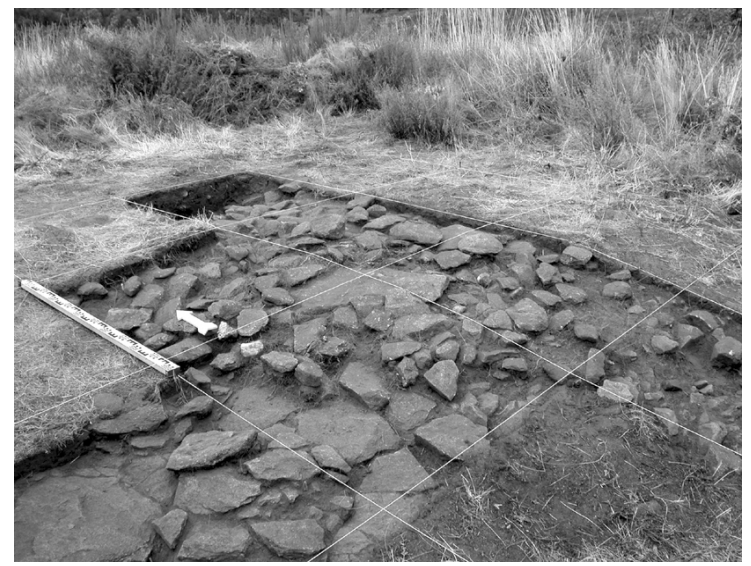

Fig. 11 - Fotografia geral do monumento após a decapagem inicial.

Fig. 11 - General view of the monument after beginning of the excavation
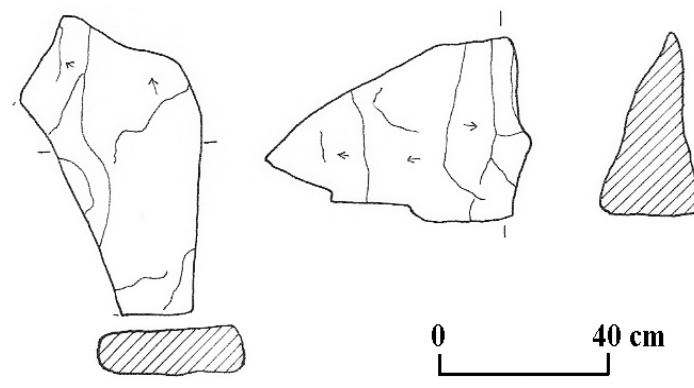

Fig. 12 - Esteio $n^{0} 1$ e fragmento do esteio $n^{0} 2$.

Fig. 12 - Orthostatic $n^{\circ} 1$ and fragmento of $n^{\circ} 2$. 
Dada a intensidade dos trabalhos agrícolas desenvolvidos em Campo de Caparinho até meados do séc. XX, a couraça lítica superficial estava praticamente destruída, sendo apenas identificável a sua fase terminal, no quadrado C4 (Fig. 6). Assim, as pedras descobertas pela decapagem, nos restantes quadrados escavados, deverão pertencer ao contraforte (Fig. 9).

\subsubsection{A câmara}

$\mathrm{Na}$ área central do monumento, detectámos dois esteios fracturados e tombados para o interior da câmara (Fig. 9, 10 e 11). Um deles, que designámos por esteio $\mathrm{n}^{\circ} 1$, encontrava-se nos quadrados B2, $\mathrm{B} 3, \mathrm{C} 2$ e C3, aflorando parcialmente à superfície. Após ter sido levantado, verificámos que a sua superfície interna tinha sido alisada como se tivesse sido preparada para ser pintada. Este alisamento confere-lhe um tom amarelado que supomos ser da própria rocha. Não registámos pinturas ou gravuras, mesmo em observação nocturna. Na sua provável posição original teria cerca de $0.76 \mathrm{~m}$ de altura (Fig. 12 e 13).

$\mathrm{O}$ esteio $\mathrm{n}^{\circ} 2$, fracturado no topo, tinha ainda $0.42 \mathrm{~m}$ de altura. Também foi alisado na superfície interna onde se verificava a mesma tonalidade amarelada existente no esteio $\mathrm{n}^{\mathrm{o}} 1$ (Fig. 12).

Na camada 1 do quadrado B3 registámos o que interpretámos como uma possível cama de esteio composta por pequenas lajes fincadas na vertical (calços?), definindo uma área de contorno oval, com cerca de $0.22 \mathrm{~m}$ de comprimento por $0.10 \mathrm{~m}$ de largura (Fig. 10, 13 e 14).

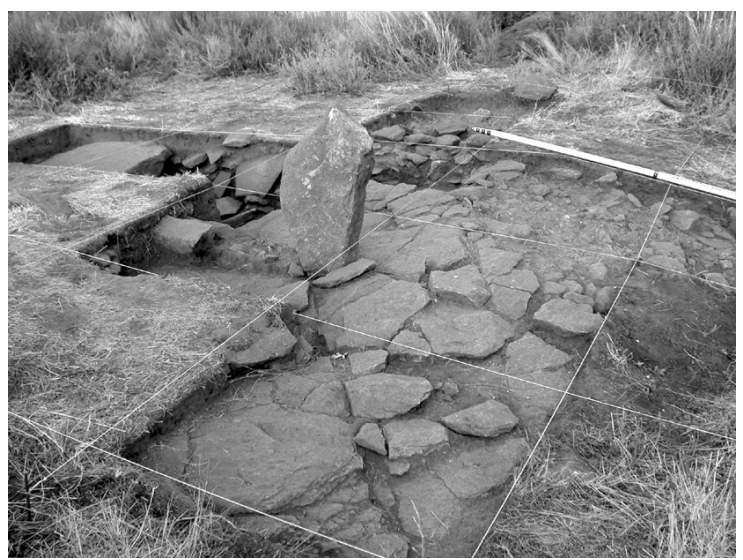

Fig. 13 - O monumento após a escavação integral das sanjas $\mathrm{S}-\mathrm{N}$ e Este. O esteio $\mathrm{n}^{\mathrm{o}} 1$ foi colocado na posição que cremos original, ao lado duma "cama" doutro esteio.

Fig. 13 - General view of the monument after the excavation of the ditches South-North and East. The orthostatic 1 was placed in the original position, along with a "bed" of another orthostatic.
Dispunham-se, sensivelmente, ao lado da eventual cama do steio $\mathrm{n}^{\circ} 1$, caso e ste tenha caído sem ter sido grandemente deslocado.

Dado o estado de destruição da câmara, a determinação das suas características torna-se extremamente difícil. Apenas podemos presumir que seria fechada e não muito grande nem alta, tendo em conta as dimensões dos esteios.

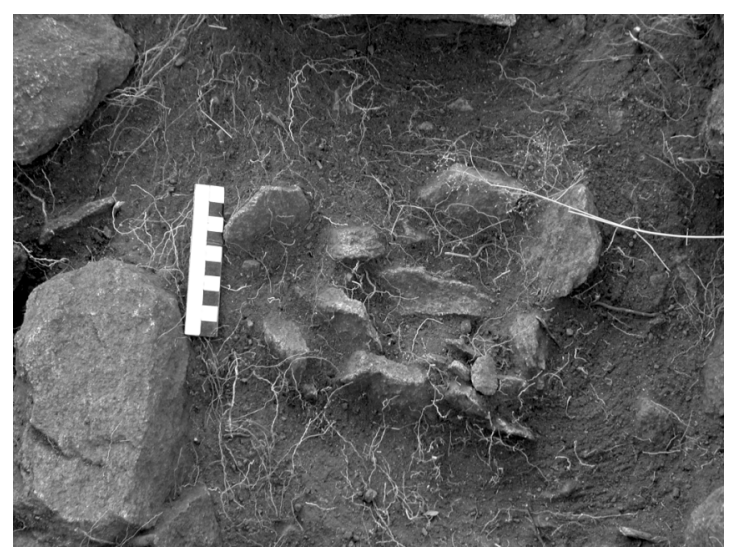

Fig. 14 - Pormenor da "cama" do esteio.

Fig. 14 - Detail of the orthostatic "bed".

\subsection{Deposições}

Os vestígios de oferendas depositadas neste monumento são escassos o que pode ser atribuído às condições de perturbação e destruição descritas anteriormente.

\subsubsection{Cerâmicas}

$\mathrm{Na}$ camada 0 do quadrado $\mathrm{C} 4$, além de um fragmento de cerâmica actual, encontrámos dois fragmentos de panças de fabricos manuais, de pastas arenosas, de cores escuras e alisados nas superfícies externas. Não pertenciam ao mesmo recipiente pois as texturas diferiam de forma significativa, sendo uma das panças grosseira e a outra mediana.

Também, na camada 0 do quadrado $\mathrm{C} 1$, se encontrou um fragmento de uma pança arenosa, grosseira, mal cozida, de cor acastanhada, já corroída, atribuível à Pré-História. Na camada 3 do quadrado $\mathrm{C} 4$, na área que supomos corresponder a uma perturbação posterior à construção inicial do contraforte, exumámos um fragmento de pança com características técnicas semelhantes aos anteriores mas de pasta mais grosseira e de coloração alaranjada. Nenhum deles fornece forma. 


\subsubsection{Líticas}

O material lítico também é escasso. Apenas foi exumado um cristal de quartzo na camada 5 do quadrado $\mathrm{C} 3$, um fragmento de seixo branco rolado e achatado (do rio), fumigado, na camada 4 do quadrado $\mathrm{C} 4$, ou seja, na lareira aí detectada, e um fragmento de seixo quartzítico, rolado, sem retoque, na camada 2 do quadrado $\mathrm{C} 3$.

\subsubsection{Ecofactos}

Vários carvões foram retirados da estrutura de combustão do quadrado $\mathrm{C} 4$, camada 4 , quer para análise de antracologia, quer de radiocarbono.

\section{ANÁlises de Antracologia}

As análises de antracologia permitiram determinar que a matéria vegetal predominantemente queimada na lareira foi $o$ Pinheiro de tipo silvestre (Pinus tipo silvestres), apesar de ter aparecido um fragmento de Urze ou Arando (Ericacea), presumivelmente usado para acender a fogueira (Isabel Figueiral - informação oral).

\section{ANÁLISES POR RADIOCARBONO}

A datação de carvão de pinheiro que se publica (quadro 1) é proveniente do laboratório Beta Analityc Inc., Miami, USA, tendo sido usada para a sua calibração a curva de M. Stuiver et al. (1998).

Quadro 1 - Idade obtida por $\mathrm{C}^{14}$, em anos BP. Table - Radiocarbon age in years BP

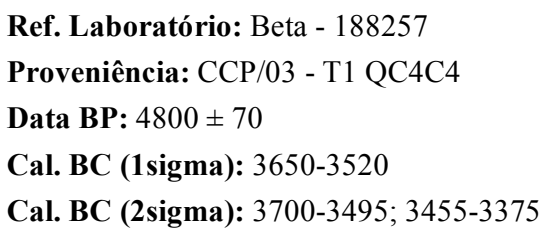

Como se pode verificar pelo resultado da análise, os troncos de pinheiro usados na estrutura de combustão, deverão datar-se, muito provavelmente, do segundo quartel do IV milénio AC, tendo em conta a calibração a 1 e a 2 sigma. Esta data afigura-se-nos aceitável para a construção do monumento, dado que a lareira, de onde foram retirados os carvões para análise, parece ter sido contemporânea do momento da erecção deste imóvel. Aguardamos, no entanto, os resultados de uma datade AMS, a partir de um pequeno ramo de Eriacacea, para precisar a cronologia do monumento.

\section{DiscuSSÃo}

Do que nos foi possível observar no decorrer da escavação, o túmulo 1 de Campo de Caparinho seria de pequenas dimensões, com cerca de $2.80 \mathrm{~m}$ de diâmetro, ao nível do contraforte, e cerca de $0.80 \mathrm{~m}$ ou $0,90 \mathrm{~m}$ de altura tendo em atenção o que nos pareceu a posição correcta do esteio $\mathrm{n}^{\mathrm{o}} 1$.

Trata-se de um monumento funerário atípico, dado ter sido construído em cima de um afloramento rochoso, o que permitiu o reaproveitamento de muitos blocos em desintegração, numa clara economia de esforço e de recursos.

Curiosamente, na área onde o afloramento é mais baixo, há indicadores de uma construção "clássica", caracterizada por contraforte, terras do tumulus e couraça superficial, embora esta seja vestígial.

Este monumento seria provido de uma câmara, aparentemente simples, com vários esteios. Os que observámos foram alisados, na face interna, o que lhes conferiu uma cor amarelada.

Com excepção dos ecofactos e de alguns artefactos líticos, os fragmentos cerâmicos eram escassos e encontravam-se descontextualizados, dada a violação total da câmara e a grande destruição do tumulus.

Mesmo assim, a sua heterogeneidade em termos de pastas, cores e de acabamento externo, indicia o depósito de vários recipientes. O cristal de quartzo talvez se deva considerar in situ, pois foi encontrado no interior das terras do contraforte, assim como o fragmento de seixo branco, colocado na estrutura de combustão.

No entanto, a importância do túmulo 1 de Campo de Caparinho não se esgota nestas ilações, de âmbito descritivo, pois o local onde foi construído, a forma como tal se efectuou e as práticas aí realizadas, constituem actos sociais eivados de inúmeras significações simbólicas que permitem outra ordem de interpretações.

Em primeiro lugar, verifica-se que este imóvel, assim como outros entretanto desaparecidos no local, foram implantados numa plataforma relativamente fechada, rodeada por afloramentos rochosos, outeiros e esporões, tendo apenas ampla visibilidade para o vale do rio Assureira que corre nas proximidades.

Tal disposição espacial permite admitir, embora como hipótese de trabalho, uma possível relação entre a água (ou o seu movimento) e a morte, igualmente "legível" a partir da deposição de um seixo do rio, na lareira existente sob o tumulus. A existência desta lareira, que cremos fundacional, poderá indiciar, igualmente, ritos associados ao 
fogo, comuns em construções megalíticas peninsulares e europeias. Esta estrutura, provavelmente usada apenas uma vez, dada a uniformidade do combustível escolhido (Pinheiro de tipo silvestre), poderia ter atingido grandes temperaturas e provocado chamas altas e bem visíveis, num efeito cénico premeditado. A deposição do referido seixo branco de origem fluvial, no seu interior, permite colocar a hipótese de que teria existido a intenção de associar a água ao fogo, num universo ideológico que valorizaria a importância de elementos de significação contrária, no momento da morte.

Em segundo lugar, a colocação de um cristal de quartzo e de vários quartzos leitosos, feldspatos e xistos, no interior do contraforte, também revela deposição intencional de minerais e rochas existentes nas proximidades, o que poderá encararse como resultante de acções ritualizadas, associadas à importância simbólica dos diferentes elementos petrográficos na natureza. Do mesmo modo é intencional o polimento da face interna dos esteios que ganham um tom amarelado, talvez revelador de uma simbologia das cores relacionada com o mundo dos mortos.

Em terceiro lugar, é de supor a ocorrência de ritos que pressupõem oferendas aos corpos, materializados pela deposição de recipientes cerâmicos no interior da câmara.

Outra questão que nos parece importante, é o facto deste monumento se ter adossado e adaptado a um afloramento de uma rocha distinta das que comummente afloram à superfície do local, razão pela qual presumimos que este acidente geomorfológico teve uma significação especial para os seus construtores, tanto mais que a matéria-prima para a sua consecução teria sido facilmente obtida em afloramentos graníticos da área.

Deste modo, é verosímil admitir que este microlocal já tivesse uma história, antes da construção do túmulo, mas que só a partir deste momento as propriedades, eventualmente conferidas a este lugar natural, tivessem sido intencionalmente associadas à(s) personagem(ns) aí enterrada(s). Tal poderia ter contribuído para transformar estes mortos em agentes ao serviço da coesão grupal ou inter-grupal das comunidades neolíticas que viveram neste território. Assim sendo, é verosímel admitir que este local se poderia ter transformado num "lugar mítico" para as gerações posteriores que o terão mantido simbolicamente activo, através de diferentes "histórias", monumentos e respectivos ritos e cerimónias a eles associados. Tal parece estar de acordo com o facto de Campo de Caparinho apresentar diferentes manifestações de interacção física e simbólica com o meio, datáveis de entre o Neolítico Médio/Final até à Idade do Bronze.

Esta hipótese, assim como as anteriormente levantadas devem, naturalmente, ser testadas no âmbito de novos projectos de investigação interdisciplinares a desenvolver nesta pequena área privilegiada do Nordeste transmontano.

\section{BibliografiA}

BettencourT, A.M.S. (2004). Um caso paradigmático de património arqueológico e antropológico na fronteira de Portugal e Galiza, Actas do $I^{\circ}$ Congresso Internacional Investigação e Desenvolvimento Sócio-Cultural, Associação para a Investigação e Desenvolvimento SócioCultural (AGIR), Paredes de Coura, publicado em CDROM com a referência BETTENCOURT.PDF.

BETTENCOURT, A.M.S. (2006). A transformação da paisagem e a construção de lugares de memória durante a Pré-História Recente do Norte de Portugal: o vale do Assureira, in Actas das XVI Jornadas Sobre a Função Social do Museu. Ecomuseu do Barroso - Identidade e Desenvolvimento, Minom - Movimento Internacional para uma Nova Museologia, Ed. Câmara Municipal de Montalegre e Ecomuseu do Barroso, Montalegre, pp. 109 - 123.

Bettencourt, A.M.S. \& DINIS, A. (2007). Arquitecturas e transformação de espaços naturais na Pré-História Recente do Norte de Portugal: Campo de Caparinho, Vilar de Perdizes, in Susana O. Jorge, Ana. M. S. Bettencourt \& Isabel Figueiral (eds.) A concepção das paisagens e dos espaços na Arqueologia da Península Ibérica. Actas do IV Congresso de Arqueologia Peninsular, Setembro de 2004, Universidade do Algarve, pp. 121- 130.

Bettencourt, A.M.S.; SAnChes, M.J.; Dinis, A.P. \& CRuZ, C. S. (2004). The rock engravings of Penedo do Matrimónio in Campo de Caparinho, Vilar de Perdizes, Montalegre (Northern Portugal), Journal of Iberian Archaeology, 6, Porto, ADECAP, pp. 62 - 82.

StUIVER, M.; REIMER, P.J.; BARD, E.; BECK, J.W.; BURR, G.S.; Hughen, K.A.; Kromer, B.; Mc CORMAC, G.; van der Plight, J. \& SPURK, M. (1998). INTCAL 98 Radiocarbon Age Calibration, 24000 - 0 cal BP. Radiocarbon, 40 (3), pp. 1041-1084.

TeiXeIra, C. \& Assunção, C.T. (1970). Carta Geológica de Portugal na Escala 1/50 000. Notícia Explicativa da Folha 2-D. Vilar de Perdizes, Serviços Geológicos de Portugal. 



\title{
CAÇA E PASTORÍCIA NO CALCOLÍTICO DO NW DE PORTUGAL: O CASO DA ESTAÇÃO ARQUEOLÓGICA DE BITARADOS
}

\author{
JoÃo Luís CARDoso* \& AnA M. S. BeTtenCourT**
}

Resumo

\begin{abstract}
Os autores publicam as primeiras evidências arqueozoológicas relacionadas com a pastorícia e com a caça detectadas no Calcolítico do Noroeste do País, recolhidas no sítio arqueológico de Bitarados (concelho de Esposende) as quais foram objecto de comparação com os resultados obtidos para outras áreas do Noroeste Peninsular.
\end{abstract}

Palavras - chave: Noroeste de Portugal, Calcolítico, restos osteológicos, reconstituição paleoambiental.

Abstract

Hunting and pastoralism in the Calcolithic of the NW of Portugal: the case study of Bitarados The authors publish the first bones of animals related to the pastoral and the hunting found in the Calcolithic of the Northwest of Portugal, collected in the archaeological site of Bitarados (municipality of Esposende) which have been compared with results for other areas of the Northwest of Iberia.

Key - words: NW of Portugal, Calcolithic; animal remains, paleoenvironmental reconstitution.

\section{INTRODUÇÃo}

Os trabalhos arqueológicos realizados em Bitarados, durante os meses de Julho e Agosto de 2002, tiveram como objectivo contextualizar, em termos cronológicos e culturais, o espólio recolhido em escavações antigas e efectuar recolhas de restos passíveis de contribuir para a reconstituição paleoambiental da paisagem da Pré-História Recente do Noroeste de Portugal.

Das escavações realizadas por um dos signatários deste texto (A.M.S.B.), no âmbito do projecto "A reconstituição da paisagem no EntreDouro-e-Minho, desde os meados do III aos finais do II milénios $A C$ ”, resultou uma primeira notícia onde se dá conta da estratigrafia, das estruturas, de parte do espólio e se apresenta uma proposta da cronologia interna deste sítio, com diferentes fases de ocupação/abandono inseríveis no Calcolítico regional (BETTENCOURT et al., 2003). Num segundo e terceiro artigos publicaram-se os resultados das análises de antracologia, de paleocarpologia e de radiocarbono, importantes pelas informações paleoambientais que forneceram para as comunidades existentes durante a $1^{\mathrm{a}}$ metade do III milénio AC (Figueiral \& BettenCOURT, 2007; BETTENCOURT et al., 2007).

Com este trabalho pretende-se dar a conhecer os resultados arqueozoológicos obtidos com base nas análises das amostras exumadas durante as escavações, completando, deste modo, a informação paleoambiental recolhida anteriormente para este local.

\section{LOCALIZAÇ̃̃O ADMINISTRATIVA E AMBIENTAL}

A estação arqueológica de Bitarados, localiza-se no lugar da Igreja, freguesia de Vila Chã, concelho de Esposende, distrito de Braga, em pleno planalto de Vila Chã, de baixa altitude, sobranceiro à plataforma litoral e ao Oceano Atlântico (Fig. 1).

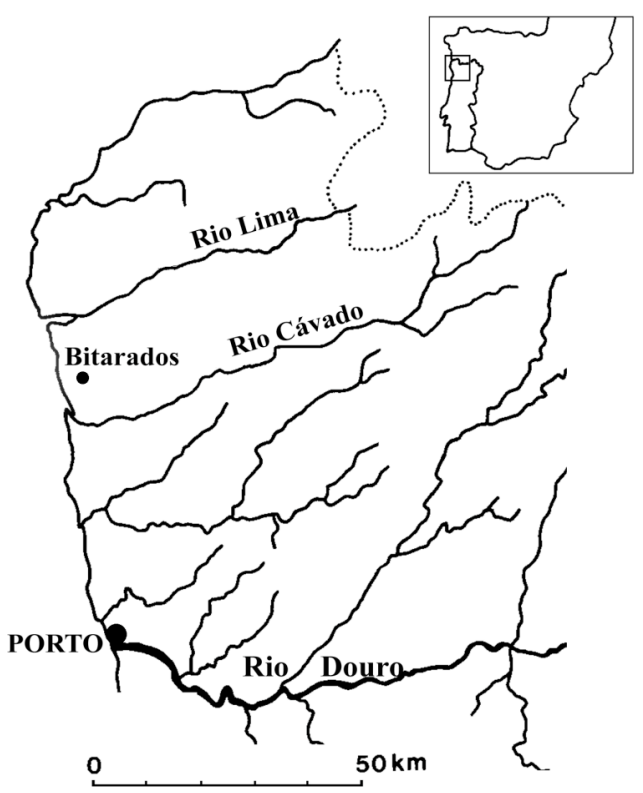

Fig. 1 - Localização de Bitarados no NW de Portugal.

Fig. 1 - Location of Bitarados in NW of Portugal.

* Universidade Aberta. E-mail: arqueolo@univ-ab.pt

** Universidade do Minho; Centro de Investigação Transdisciplinar de Cultura, Espaço e Memória - CITCEM (Univ. do Porto e Univ.Minho) E-mail: anabett@uaum.uminho.pt 
Implanta-se num alvéolo, com um ligeiro pendor para nascente, no sentido do ribeiro da Igreja, que corre para o de Peralta. Esta implantação, torna o local muito abrigado e ameno. A proximidade do ribeiro de Peralta, eixo principal de drenagem da parte média do alvéolo para o Oceano Atlântico, permitiu às populações de Bitarados o acesso fácil, durante todo o ano, a um recurso fundamental, a água. $\mathrm{O}$ posicionamento topográfico de Bitarados caracteriza-se, igualmente, pela fácil acessibilidade às áreas de maior altitude do planalto e à plataforma litoral (Fig. 1 e 2).

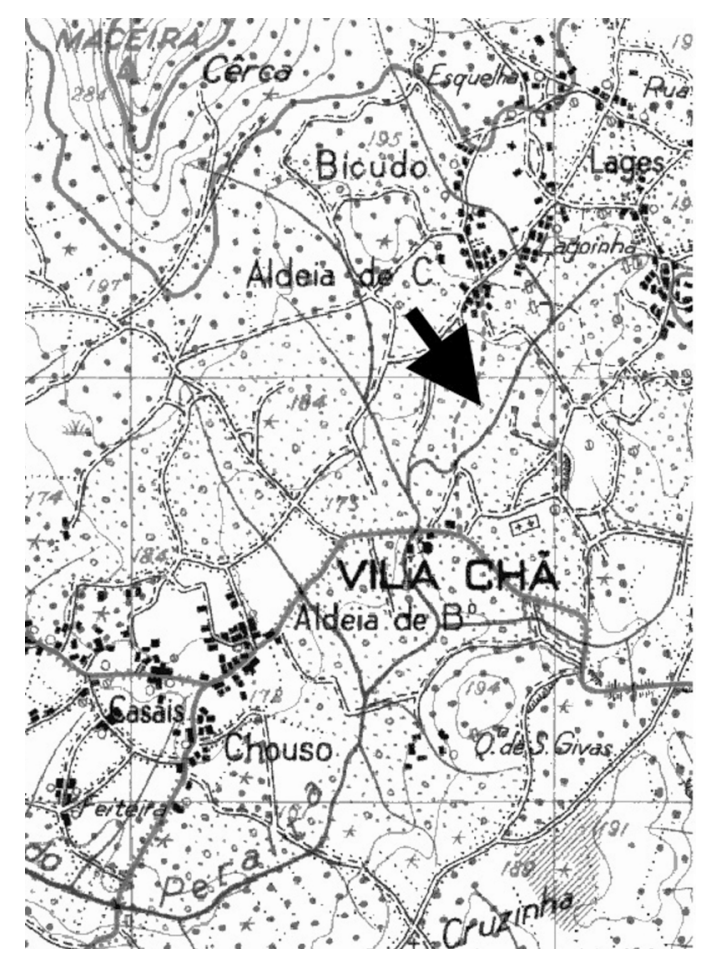

Fig. 2 - Localização da estação arqueológica de Bitarados na Carta Militar de Portugal.

Fig. 2 - Location of the archaeological site of Bitarados in the "Carta Militar de Portugal".

Segundo a Carta Geológica de Portugal, a estação está implantada numa mancha de aluviões modernas, sendo o substrato rochoso composto por granito porfiróide de grão grosseiro a médio. Para oeste, a pouco mais de $500 \mathrm{~m}$, e para sul, a cerca de $1 \mathrm{~km}$, ocorrem manchas de xistos e grauvaques, fortemente metamorfizados e afloramentos de quartzitos intercalados.

$\mathrm{Na}$ actualidade, a zona onde se implanta a estação é um espaço aberto, com áreas urbanizadas e de exploração agrícola, com milho, vinha e oliveiras (Fig. 3).

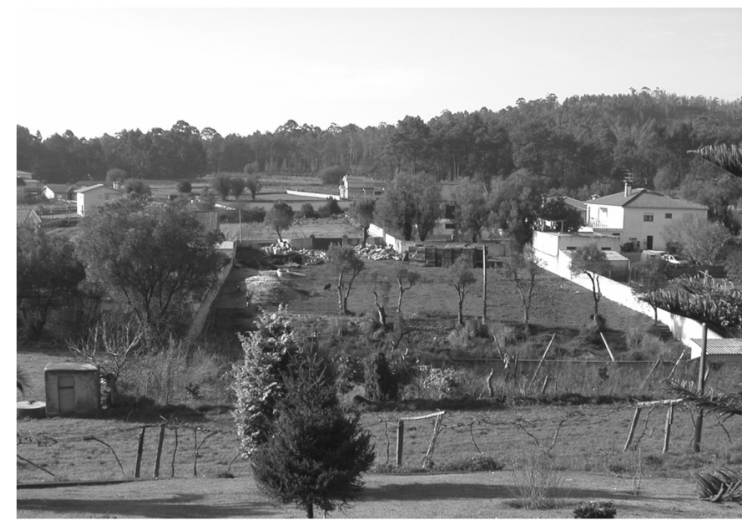

Fig. 3 - Vista geral de Bitarados.

Fig. 3 - General view of Bitarados.

\section{O SÍTIO ARQUEOLÓGICO}

Apesar da exiguidade das sondagens realizadas em Bitarados (Fig. 4) a distribuição dos achados cerâmicos detectados à superfície, permitiu colocar a hipótese de que esta estação arqueológica ocuparia uma extensão considerável.

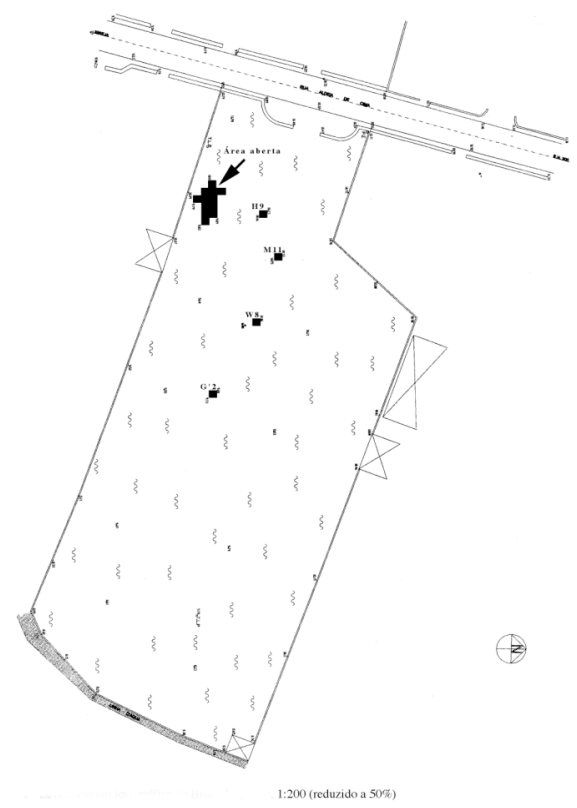

Fig. 4 - Planta das escavações arqueológicas.

Fig. 4 - Map of topographic survey.

Assim, é provável que a área escavada corresponda apenas a uma zona periférica de um sítio calcolítico de grandes dimensões, à semelhança de outros que têm sido identificados recentemente, no Noroeste Peninsular (GIANOTTI GARCIA \& CANCELA CEREIJO, 2005; CARDOSO, no prelo) $)^{1}$.

No Douro Litoral, no concelho da Maia, apareceu, recentemente, um sítio com fossos e fossas, atribuíveis a este período, apresentado, em parte, na comunicação de António Valera e João Rebuge, intitulada $O$ recinto de fossos da Pré-História Recente da Barca (Maia): trabalhos da ERA Arqueologia S.A., no âmbito do Colóquio ERA Arqueologia/6, 2 e 3 de Março, 2007, em Lisboa. 
As escavações arqueológicas permitiram perceber a existência de uma larga diacronia de ocupação, perceptível em cinco fases, que designámos por Bitarados I, II, III, IV e V e que se desenvolveram, grosso modo, entre 2880 a 2460 AC.

Bitarados I corresponde à ocupação mais antiga do local, associando-se à fossa 1 dos quadrados $\mathrm{H} 1$ e I1, à lareira 3 do quadrado H9 (camada 3 e 3b') e, provavelmente, à camada 4 do $G^{\prime} 2$. Bitarados II e III reporta-se à fase de maior extensão do sítio, onde são nítidas sobreposições de várias estruturas, como pavimentos argilosos, lareiras e buracos de poste, existentes na camada 3 e datáveis do $1^{\circ}$ quartel do III milénio AC. Bitarados IV e V, corresponde à sobreposição de lareiras existentes na camada 2 e relaciona-se com o momento terminal de ocupação do local, provavelmente já no $2^{\circ}$ quartel do III milénio AC.

De uma forma geral, o tipo de estruturas, artefactos e ecofactos, analisados em associação, indiciam a possibilidade deste lugar ter tido uma longa diacronia. Do mesmo modo parece verosímil admitir que estas comunidades teriam desenvolvido um agricultura cerealífera, a par da pastorícia.

A presença de fragmentos de moinhos, dormentes e moventes, e os resultados das análises de paleocarpologia e de antracologia parecem apoiar a interpretação de que as comunidades de Bitarados I, II e III, cultivavam cereais e leguminosas. No primeiro caso, registámos o trigo de grão nu e a cevada. No segundo, a fava. A presença de ervas daninhas associadas às culturas de Inverno e de Verão, como o Galium cf. Aparine (Amor-de-hortelão) e o Polygonum sp., sugerem que as actividades agrícolas se realizavam durante todo o ano. De igual modo, a identificação de fabáceas, urzes e cistáceas, plantas colonizadoras de terrenos abandonados, testemunha o forte impacto humano sobre o meio.

Nas ocupações mais recentes, ou seja, em Bitarados IV e $\mathrm{V}$, permanecem as evidências do cultivo do trigo, assim como ervas daninhas e
Rumex sp., planta que poderá indiciar a existência de prados. A recolecção de bolotas, amoras e rabanetes selvagens, também foi efectuada.

\section{MATERiAL ESTUdADo}

No total, recolheram-se 96 restos faunísticos, dos quais apenas foi possível a classificação taxonómica de 40, dado o estado muito fragmentário e a exiguidade dos restantes (Quadro 1).

Nos níveis mais recentes, o número de amostras era muito mais reduzido do que nos restantes. Com efeito, em Bitarados $\mathrm{V}$ recolheram-se apenas 6 fragmentos ósseos e em Bitarados IV somente 5. Cremos que tal se deve, em parte, aos processos tafonómicos, que destruíram os restos existentes naqueles níveis, em resultado da maior lixiviação dos terrenos, associada e em parte resultante das actividades antrópicas relacionadas com a agricultura, que também terá contribuído para a fragmentação e consequente destruição dos restos ali existentes.

Nos níveis mais antigos, a amostragem aumenta, tendo sido recolhidos 17 restos em Bitarados III, 37 em Bitarados II e 31 em Bitarados I. A preservação de um maior número de amostras nestes níveis deverá relacionar-se com o encharcamento constante dos solos, ao longo de todo o ano, propício à conservação de matéria orgânica em ambiente pouco oxigenado, assim como ao facto de se encontrarem mais protegidos dos efeitos resultantes das práticas agrícolas, devido à proximidade da já referida linha de água.

A distribuição das amostras também é significativa, estando quase todas elas associadas a contextos de lareiras ou de pavimentos (Quadro 1, Fig. 5 e 6), sendo de destacar a existência de alguns restos no interior da fossa detrítica $\mathrm{n}^{\mathrm{o}} 1$, em Bitarados I, em associação com restos cerâmicos e líticos.

Quadro 1: Distribuição das amostras e seus contextos de achado.

Table 1: Distributions of the samples and its contexs of discovery.

\begin{tabular}{|l|c|l|}
\hline Referência & Número de Amostras & Contextos \\
\hline Bitarados V & 5 & $\begin{array}{l}\text { Pavimento/Lareira 1 de M11; em redor da Lareira 2 de } \\
\text { F0/F1 e dispersos. }\end{array}$ \\
\hline Bitarados IV & 6 & \begin{tabular}{l} 
Em redor da Lareira 3 de D2/E2/E3 e dispersos. \\
\hline Bitarados III
\end{tabular} If $^{\text {Pavimento 2 de M11; Pavimento 1 de H9 e dispersos. }}$ \\
\hline Bitarados II & 37 & $\begin{array}{l}\text { Áreas da Lareira de H1/I1; Cabana 1 e Cabana 2; } \\
\text { Pavimento 3 de M11 e dispersos. }\end{array}$ \\
\hline Bitarados I & 31 & Fossa 1 de H1/I1; Lareira 3 de H9 e dispersos. \\
\hline
\end{tabular}


A distribuição das amostras também é significativa, estando quase todas elas associadas a contextos de lareiras ou de pavimentos (Quadro 1, Fig. 5 e 6), sendo de destacar a existência de alguns restos no interior da fossa detrítica $\mathrm{n}^{\mathrm{o}} 1$, em Bitarados I, em associação com restos cerâmicos e líticos.
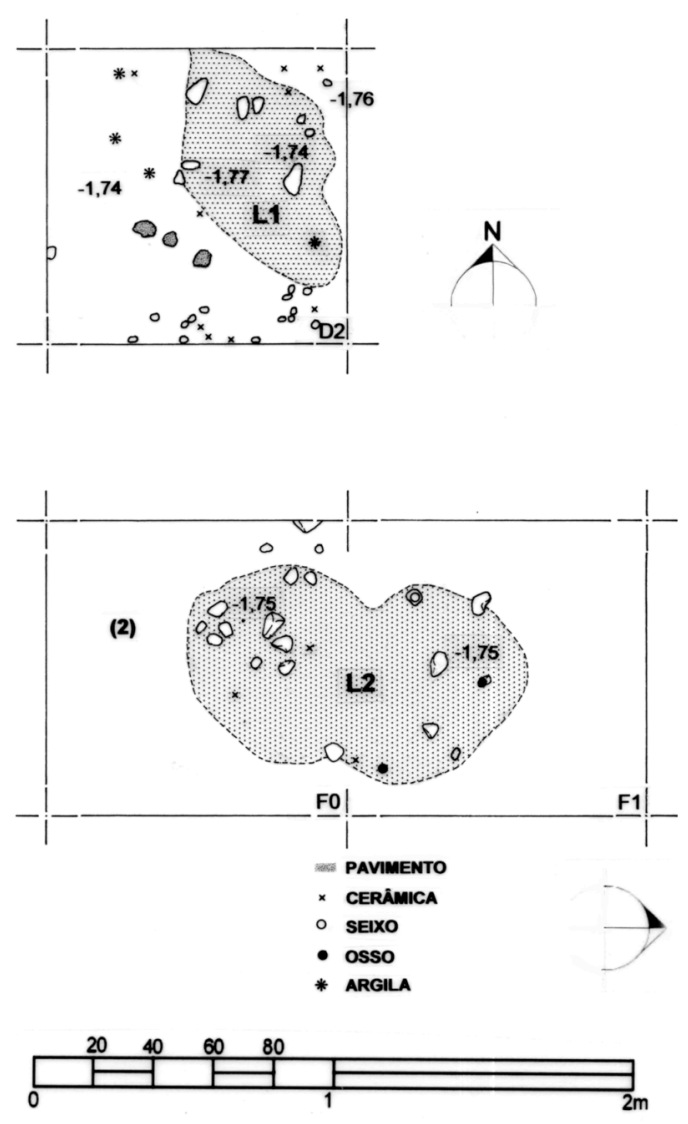

Fig. 5 - Lareiras de Bitarados V.

Fig. 5 - Fireplaces of Bitarados V.

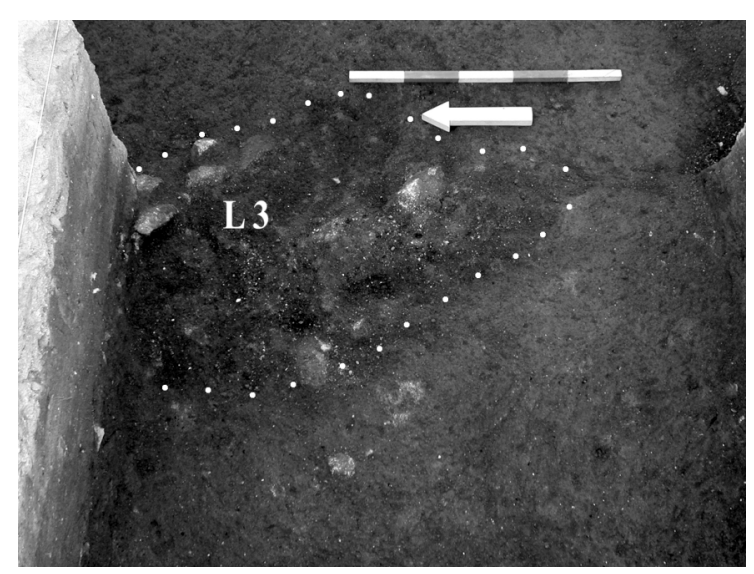

Fig. 6 - Lareira 3 de Bitarados IV.

Fig. 6 - Fireplace $n^{\circ} 3$ of Bitarados IV.

\section{RESUltados OBTIDOS}

Os restos faunísticos de Bitarados demonstram a existência dominante de rebanhos de ovinos/caprinos, cujos restos, profundamente fragmentados e incompletos, não permitiram identificação anatómica nem, muito menos, a separação entre as duas espécies domésticas, afastada a possibilidade de algum deles pertencerem a cabra-montês. Com efeito, trata-se, invariavelmente, de exemplares que denotam a presença de indivíduos pouco robustos e de pequeno porte, incompatíveis com a hipótese mencionada.

O material reportável a ovinos/caprinos resumese, na quase totalidade dos casos, a pequenas esquírolas de ossos longos indeterminados, que ascendem a cerca de 35 exemplares, distribuídos por toda a área escavada da estação. A ausência de dentes, pertencentes à parte do esqueleto com menor interesse alimentar, não obstante corresponderem a peças com elevada resistência, parece indicar que as peças de carne, na área investigada do sítio arqueológico, chegariam já libertas das partes sem interesse alimentar: o esquartejamento far-se-ia em outro lado. Com efeito, as partes do esqueleto representadas, correspondem à porção da carcaça com maior interesse, do ponto de vista do aproveitamento da carne (ossos longos dos membros anterior e posterior).

Por outro lado, é frequente as marcas de sobreaquecimento, com alteração da coloração (passagem ao cinzento-esbranquiçado, por transformações minerais, fenómeno que se atinge entre os $600^{\circ} \mathrm{C}$ e os $650^{\circ} \mathrm{C}$ ) e da estrutura óssea (fendilhamento dos ossos por dessecação provocada pelo calor). Tais marcas são, provavelmente, o resultado do hábito, também observado em outros contextos geográficos e culturais, como nos povoados do Bronze Final do sul da Beira Interior (ANTUNES, 1992), do lançamento para o fogo dos ossos, depois de consumida a carne, eventualmente para o aproveitamento secundário dos produtos combustíveis que os mesmos contêm. Os próprios contextos de achado estão de acordo com esta hipótese.

Restos identificáveis de ovinos/caprinos, que não sejam porções de ossos longos, são a excepção: apenas se notou a presença de um astrágalo esquerdo, talvez de juvenil, dadas as pequenas dimensões, e de uma porção da calote craniana e de um possível fragmento de pelvis (?), igualmente com indícios de estalamento por dessecação.

Um dos aspectos a salientar na reduzida e muito incompleta amostragem estudada dos restos de ovinos/caprinos reside na pequenez e gracilidade dos exemplares, aspecto que nem mesmo as 
diminutas porções dos fragmentos disponíveis impede de observar; tal facto prende-se, provavelmente, com o abate dos animais em estádio ainda juvenil, conclusão que é apoiada por alguns escassos indícios, como o tamanho do astrágalo identificado.

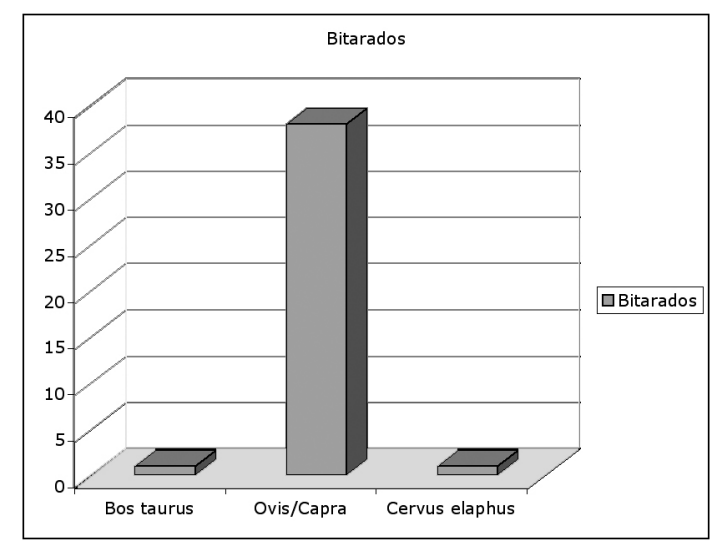

Fig. 7 - Percentagem das espécies encontradas em Bitarados.

Fig. 7 - Percentage of species found in Bitarados.

A única evidência de fauna caçada corresponde a uma porção anterior de segunda falange de veado (Cervus elaphus), conservando a superfície articular proximal, para além de uma esquírola inclassificável que, pelas dimensões tanto pode ser de veado como de boi doméstico; a pertencer a esta última espécie, seria o único exemplar identificado na estação (Fig. 7).

Deste modo, a economia alimentar da população calcolítica de Bitarados, em termos de carne consumida, centrava-se quase em absoluto no pastoreio de ovinos/caprinos. Animais domésticos de maior porte, como o boi, seriam excepcionais, a terem existido, como é natural, do mesmo modo que a caça de cervídeos (apenas representada por um resto de veado) seria também esporádica.

Estes resultados, por pouco representativos que possam ser, afiguram-se de interesse, por serem até ao presente os únicos para a área geográfica e a época em apreço, justificando-se assim comparações com os resultados existentes para o Noroeste peninsular, apesar da diversidade de contextos e de cronologias o que permitirá, apenas, inferir tendências gerais.

\section{Discussão}

No Noroeste peninsular foram recentemente estudadas as associações de mamíferos de duas grutas. Referimo-nos à da Pala da Vella, Rubiá, Ourense (FERNÁNDEZ RODRÍGUEZ et al.,1996; FERnÁNDEZ RodríGUEZ, 2001; FERnÁNDEZ
Rodríguez \& PÉrez OrTIZ, 2007) e à de Tres Ventanas, Toral de los Vados, León (FERNÁNDEZ RODRÍGUEZ \& PÉREZ ORTIZ, 2007).

$\mathrm{Na}$ Pala da Vella, ao nível 2, inserível ao Neolítico Final/Calcolítico, corresponde a seguinte associação, no que ás espécies com maior interesse alimentar diz respeito:

Boi doméstico - 4 restos identificados (4,8\%);

Ovelha - 6 restos identificados;

Ovelha/Cabra - 52 restos identificados (69,9\%);

Veado - 14 restos identificados (16,9\%).

No nível 1, atribuído ao Bronze Inicial, a distribuição observada é a seguinte:

Boi - 4 restos identificados $(5,1 \%)$;

Ovelha - 3 restos identificados;

Ovelha/Cabra - 155 restos identificados $(75,5 \%)$;

Cabra - 4 restos identificados;

Veado - 5 restos identificados (6,2\%);

Porco doméstico - 25 restos identificados (11,5\%).

Comparando estes dois conjuntos com o de Bitarados, verifica-se que este se aproxima mais do primeiro, com o qual, do ponto de vista cronológico, terá também maiores afinidades. Em ambos, o porco doméstico, que não ocorre (Bitarados), ou ocorre em quantidades insignificantes (Pala da Vella, com apenas 2 restos identificados, a que correspondem $0,2 \%$ ), terá sido substituído pelo veado, espécie que, no conjunto galego mais moderno, evidencia nítido decréscimo.

Seja como for, do Neolítico Final ao Bronze Inicial, evidencia-se, na região de Ourense, tal como em Bitarados, uma actividade pastoril dominada pela criação de ovinos/caprinos.

Tendo presente a quantidade de carne consumida, a sequência por ordem decrescente de importância, considerando como um só os dois conjuntos de Pala da Vella, é a seguinte: $1^{\circ}$ ovinos/caprinos; $2^{\circ}$ - veado; $3^{\circ}$ - boi doméstico e $4^{\circ}$ - porco doméstico.

Esta sequência encontra-se respeitada no conjunto de Bitarados, pese embora as fortes limitações da sua representatividade, pela escassez numérica da amostra.

Os restos recuperados na gruta de Tres Ventanas, pertencentes ao Calcolítico précampaniforme, denotam a seguinte distribuição:

Boi doméstico - 57 restos identificados (26\%);

Ovelha - 4 restos identificados;

Ovelha/Cabra - 80 restos identificados (39,7\%);

Cabra - 3 restos identificados;

Veado - 27 restos identificados (12,3\%);

Corço - 22 restos identificados (10,0\%);

Porco doméstico - 19 restos identificados $(8,7 \%)$;

Javali - 2 restos identificados (0,9\%).

De assinalar, ainda, a presença importante de corço (Capreolus capreolus), representado por 22 restos, a que correspondem $10 \%$ do total dos restos identificados. 
Ao contrário das anteriores, esta distribuição evidencia nítida dominância do consumo do boi doméstico, em detrimento dos ovinos/caprinos. Com efeito, considerando o peso da carne consumida, os autores do referido estudo indicam percentagem de 58,0\% para o primeiro, contra apenas $15,9 \%$ para o segundo conjunto, enquanto o veado ocupa o terceiro lugar, com 15,6\% da carne consumida. Este grupo faunístico exibe ainda uma maior diversidade que os anteriores, com destaque para o contributo cinegético, através da presença do corço e do javali, ausentes em Pala da Vella.

As diferenças apontadas foram apenas interpretadas como consequência das diferentes condições vigentes nas regiões naturais envolventes em cada um dos casos (FERNÁNDEZ RODRÍGUEZ \& PÉREZ ORTIZ, 2007). Assim, para aqueles autores, enquanto que na região da gruta das Tres Ventanas, num vale fluvial, se desenvolveriam pastagens, devido às condições dominantes, propícias à bovinicultura, já na região montanhosa da gruta da Pala da Vella o relevo, mais acidentado, teria determinado o predomínio dos rebanhos de ovinos. A presença significativa de corço, em Três Ventanas, só pode explicar-se através de surtidas cinegéticas às regiões montanhosas mais próximas, as quais não teriam tanta importância, no âmbito da economia alimentar dos habitantes da Pala da Vella, visto tal espécie, apesar do domínio montanhoso onde se encontra a gruta, não se encontrar representada no espectro faunístico.

Apesar de termos presentes estas observações não cremos que esta explicação se possa adequar a Bitarados, onde a nítida dominância do conjunto constituído pelos ovinos/caprinos sobre os bovinos não parece encontrar explicação nas condições naturais envolventes pois ali a bovinicultura seria possível e até favorecida pela implantação da estação num planalto de baixa altitude, de fácil acessibilidade e próximo de linhas de água, em domínios com condições necessárias à existência de boas pastagens. Assim, é provável que, além dos factores de ordem natural, tenhamos que ter em conta contextos de utilização distintos e a economia específica de cada comunidade, assim como problemas pós-deposicionais na explicação das percentagem de animais representados em cada um dos sítios em estudo.

Importa, no âmbito desta discussão, ter ainda em consideração outros conjuntos oriundos de estações de cronologia idêntica, do norte do País, embora situadas já na região transmontana. É o caso do espólio faunístico até agora recuperado no recinto murado de Castanheiro do Vento (Vila Nova de Foz Côa), objecto de estudo recente (CARDOSO \& CostA, 2004). O conjunto dos 25 restos recuperados da camada 3 , atribuída ao Calcolítico pelos arqueólogos responsáveis pela escavação, evidencia assinalável variedade, denotando uma economia alimentar proteica baseada no consumo de bovinos e de suínos (domésticos e/ou selvagens), detendo os ovinos/caprinos uma pequena importância (apenas 4 restos identificados), extensível também ao veado, representado somente por 1 resto. A dominância dos bovinos é de reter, pelo facto de a região não se apresentar especialmente propícia, na, actualidade, à criação de bovinos.

Nos níveis calcolíticos do recinto murado do Crasto de Palheiros, Murça (CARDoso, 2005), identificou-se associação faunística constituída pelos seguintes conjuntos: 1 - 35 restos atribuíveis a boi doméstico (Bos taurus), entre os quais doze restos dentários, incluindo alguns germes, sugerindo que o esquartejamento das carcaças era feito na área habitada; 2 - 21 restos de ovelha ou cabra, essencialmente constituídos por esquírolas de ossos longos, mas onde se reconheceram 9 restos dentários; de notar que, além de ossos longos, estão presentes elementos do esqueleto axial. $3-2$ restos de suídeo (desconhecendo-se se doméstico ou não), completa o conjunto.

Tal como o conjunto calcolítico do Castanheiro do Vento, também este difere do de Bitarados, pela maior importância assumida pelos grandes bovinos, os quais, em termos de quantidade de carne disponível, assumem, claramente, o lugar mais importante, embora a sua principal função pudesse não corresponder, ao fornecimento proteico. É de referir, igualmente, as condições pouco propícias da região à bovinicultura.

Outra diferença face ao conjunto em apreço, reside na ausência da componente cinegética, designadamente do veado (Cervus elaphus), o qual, certamente, estaria presente na vasta região dúricobeirã, no decurso do Calcolítico, como indicam os restos recolhidos no Castanheiro do Vento (Vila Nova de Foz Côa), atrás referidos.

Os povoados da Vinha da Soutilha e da Pastoria, ambos no concelho de Chaves, são outros dois sítios calcolíticos transmontanos cujo registo faunístico se conhece.

$\mathrm{Na}$ Vinha da Soutilha, a associação é muito pobre tendo apenas sido identificados 8 restos e ovelha/cabra e 1, com incerteza, de suídeo, para além de Lagomorfos, Roedores e Aves (LOPES, 1986). A nítida dominância do grupo dos ovinos/caprinos está, pois, em sintonia com a realidade observada em Bitarados, e, tal como aqui, os restos apresentam-se muito fracturados e reduzidos a esquírolas, embora ocorram fragmentos de peças dentárias. Neste local, há, também, referências pontuais, à acção do fogo.

No povoado da Pastoria a amostragem óssea é mais numerosa, embora as espécies domésticas dominantes sejam os ovinos, os caprinos e os 
ovinos/caprinos (LOPES, 1986). Com efeito, foi possível, tal como no caso dos conjuntos faunísticos galegos, efectuar a diferenciação entre as duas espécies em causa, embora, no caso português, a autora se tenha baseado em critérios cujos resultados merecem sérias reservas. Referimo-nos à diferenciação dos corpos vertebrais e das costelas, bem como das $1^{\mathrm{a}}$. e $2^{\mathrm{a}}$. falanges, critérios que não são passíveis de aplicar para peças soltas, escassas e incompletas, como é o caso. Deste modo, consideramos mais adequado tratar os ovinos e os caprinos como um único lote, representado por 25 peças, contra 36 de suídeos. Neste caso, também é de estranhar que sejam deste último conjunto as 17 omoplatas, mais ou menos fragmentadas, identificadas na estação, motivo que conduz a encarar a validade destes resultados com a máxima cautela.

Em suma: as bases de subsistência identificadas através do estudo do pequeno conjunto faunístico de Bitarados apresenta-se largamente dominado pelos ovinos/caprinos. Estes, à semelhança do verificado noutros contextos da mesma época, como os referidos da Galiza, serviriam, essencialmente, para a produção de carne, dado a provável idade juvenil com que foram abatidos boa parte dos animais, tendo em consideração a gracilidade e pequenas dimensões dos ossos longos, a crer nas informações fornecidas pelos restos observados, ainda que com reserva, dado o elevado grau de fragmentação que os afecta.

A caça do veado seria uma prática presente neste e noutros contextos calcolíticos portugueses, como em Castanheiro do Vento, no Alto Douro, podendo revestir mesmo grande importância, nalguns locais, como se verificou na região montanhosa de Ourense, na Pala da Vella.

Em contrapartida, é de realçar a escassez do boi doméstico em alguns dos sítios de que há informação, à semelhança do verificado em Bitarados. Esta situação poderá explicar-se por diversos factores, entre os quais, a conservação diferencial dos vestígios. Com efeito, enquanto os exemplares de menores dimensões se conservariam sem grandes problemas por, na maioria dos casos, terem sido fortemente mineralizados devido à acção do calor, ao terem sido arremessados para o lume, já os restos de maiores dimensões, por não terem conhecido idêntico destino, devido ao seu tamanho, incomportável com as dimensões de uma pequena lareira, teriam probabilidades de conservação inferiores, tendo presente a agressividade química dos solos representados nas diferentes estações arqueológicas do Noroeste peninsular. Nos contextos fechados, como os das grutas ou dos recintos com estruturas rochosas, mais protegidos das acções lixiviantes e com maiores concentrações de matéria orgânica, a conservação de tais restos estaria, pelo contrário, mais facilitada. Tal realidade poderia explicar, em parte, a nítida diferença entre a importância dos bovinos nas grutas do Noroeste e no sítio muralhado de Castanheiro do Vento e a verificada em Bitarados, onde apenas se conservaram escassos e duvidosos restos ósseos desta espécie. No entanto, também não podemos descartar a hipótese de que a presença de bovinos, em maior quantidade em Castanheiro do Vento ou na Gruta de Três Ventanas, possa estar relacionada com consumos especiais no âmbito de acções e lugares de grande significância simbólica.

Seja como for, ainda que não se revistam de indiscutível representatividade, tanto pelo número de restos, como pela composição, o pequeno conjunto faunístico pré-histórico de Bitarados tem interesse por ser o primeiro a ser estudado na região minhota, tão escassa em restos desta natureza pelas adversas condições de conservação aqui existentes.

\section{BIBLIOGRAFIA}

Antunes, M.T. (1992). Povoados do Bronze Final da Beira Baixa - Alegrios, Moreirinha e Monte do Frade: elementos arqueozoológicos. Conimbriga, Coimbra, 31, pp. 31-38.

Bettencourt, A.M.S.; Dinis, A.; CruZ, C. \& Silva, I.S. (2003). O povoamento Calcolítico do alvéolo de Vila Chã, Esposende (Norte de Portugal). Notas a propósito das escavações arqueológicas de Bitarados, Portugália, n. série, 24, Porto, pp. 29-50.

Bettencourt, A.M.S.; Dinis, A.; Figueiral, I.; Rodrigues, A.; CRUZ, C.S.; Silva, I.S.; AZEVEDO, M. \& BARBosA, R. (2007). A ocupação do território e a exploração de recursos durante a Pré-História Recente do Noroeste de Portugal, in S. O. Jorge, A.M.S. Bettencourt \& I. Figueiral (eds.) A concepção das paisagens e dos espaços na Arqueologia da Península Ibérica. Actas do IV Congresso de Arqueologia Peninsular, Centro de Estudos de Património, Departamento de História, Arqueologia e Património, Fac. de Ciências Humanas e Sociais, Universidade do Algarve, pp.149-164.

CARdoso, J.L. (2005). Restos faunísticos do Crasto de Palheiros (Murça). Contributo para o conhecimento da alimentação no Calcolítico e na Idade do Ferro no Noroeste português. Portvgalia, n. série, 26, Porto, pp. 65-75.

Cardoso, J.L. \& CostA, C. (2004). A study of the faunal assemblage from the prehistoric enclosure of Castanheiro do Vento (Vila Nova de Foz Côa). Journal of Iberian Archaeology, 6, Porto, pp. 83-92.

CARDoso, J. M. (no prelo). Escavação arqueológica no sítio préhistórico do Lugar da Forca/Barca, Maia, Actas das I Jornadas Arqueológicas da Bacia do Rio Leça, Matesinus, $\mathrm{n}^{\circ}$ 6, Ed. Câmara Municipal de Matosinhos, Matosinhos.

FERNÁNDEZ RODRÍGUEZ, C. (2001). Presencia humana en cuevas de Vadeorras: el registro arqueológico, in J.Ma San Román (coord.): Valdeorras da Prehistoria ó século XXI. Actas de la VII Semana de Historia de Valdeorras (O Barco, 1996). Instituto de Estudios Valdeorreses - Monografías $n^{\circ}$ 33 , pp. 7-72. 
Fernández Rodríguez, C. \& Pérez Ortiz, L. (2007). Caza y domesticación en el Noroeste de la Península Ibérica durante la Prehistoria. Datos arqueozoológicos, in S. O. Jorge, A. M. S. Bettencourt \& I. Figueiral (eds.) $A$ concepção das paisagens e dos espaços na Arqueologia da Península Ibérica. Actas do IV Congresso de Arqueologia Peninsular (Promontoria Monográfica, 8), Centro de Estudos de Património, Departamento de História, Arqueologia e Património, Fac. de Ciências Humanas e Sociais, Universidade do Algarve, pp. 165176.

FERNÁNDEZ RodRÍGUEZ, C.; VILLAR QUINTEIRO, R.; VARELA, P.; REY, J.M. \& ElorzA ,M. (1996). Primeros datos cronológicos y paleontológicos del yacimiento de Pala da Vella (Biobra-Ourense), in P. Ramil Rego, C. Fernández Rodríguez \& M. Rodríguez Guitián (Coord.). Biogeografia Pleistocena - Holocena de la Península Ibérica. Xunta de Galicia. Santiago, pp. 249-260.

Figueiral, I. \& Bettencourt, A.M.S. (2007) Estratégias de exploração do espaço no Entre Douro e Minho desde os finais do IV aos meados do I milénios AC, in S. O. Jorge,
A. M. S. Bettencourt \& I. Figueiral (eds.) A concepção das paisagens e dos espaços na Arqueologia da Península Ibérica. Actas do IV Congresso de Arqueologia Peninsular (Promontoria Monográfica, 8), Centro de Estudos de Património, Departamento de História, Arqueologia e Património, Fac. de Ciências Humanas e Sociais, Universidade do Algarve, pp.177 - 187.

Gianotti Garcia, C. \& C. CANCEla Cereijo (2005). Testemuña da ocupación humana durante o Neolítico Final e o período Alto-Medieval na Península do Morrazo, in F. Criado Boado \& E. Cabrejas Domíngez (coord.) Obras Públicas e Património: Estudo Arqueolóxico do corredor do Morrazo. Tapa - 35, Santiago de Compostela, pp. $50-54$.

LOPES, T.C. (1986). Análise do material ósseo das estações da Vinha da Soutilha (Mairos) e da Pastoria (Chaves), in S. O. Jorge (ed.)Povoados da Pré-História Recente da região de Chaves - $V^{a} P^{a}$ de Aguiar, Instituto de Arqueologia da Univ. de Letras do Porto, Porto, vol.I-B, pp. 1099-1123. 